\title{
Leafy spurge (Euphorbia esula) control with glyphosate plus 2,4-D
}

\author{
RODNEY G. LYM
}

Author is professor, Plant Sciences Dept., North Dakota State University, Fargo, North Dakota 58105.

\begin{abstract}
Leafy spurge control with glyphosate [ $\mathrm{N}$-(phosphonomethyl)glycine] plus 2,4-D [2,4-dichlorophenoxy)acetic acid] applied annually for 3 years alone or rotated with auxin herbicides was evaluated at 3 locations in North Dakota. Glyphosate applied with 2,4-D averaged $67 \%$ leafy spurge control 3 months after treatment which was a 10 -fold increase compared to glyphosate alone. Glyphosate plus 2,4-D applied annually for 3 years or rotated with dicamba (3,6-dichloro-2-methoxybenzoic acid) or picloram (4-amino-3,5,6-trichloro-2-pyridinecarboxylic acid) plus 2,4-D provided 80 to $90 \%$ leafy spurge control, which was similar to the standard annual picloram plus 2,4-D treatment but at 30 to $65 \%$ less cost. Herbage production was similar regardless of treatment. The absorption and translocation of ${ }^{14} \mathrm{C}-2-4-\mathrm{D}$ increased 2- to 3-fold when applied wit glyphosate compared to ${ }^{14} \mathrm{C}-2,4-\mathrm{D}$ applied alone. However, both absorption and translocation of ${ }^{14} \mathrm{C}$-glyphosate was severely reduced when applied with 2,4D compared to ${ }^{14} \mathrm{C}$-glyphosate applied alone. The increase in control when glyphosate is applied with 2,4-D may be because sublethal concentrations of glyphosate break root bud dormancy in leafy spurge, thereby increasing the amount of 2,4-D in the root. Glyphosate plus 2,4-D provided good leafy spurge control at less cost than current widely used treatments and should provide a new tool for leafy spurge management.
\end{abstract}

Key Words: dicamba, herbage production, noxious weed, picloram, rangeland weed control

Leafy spurge infests over 840,000 ha in North Dakota, South Dakota, Montana, and Wyoming and causes an annual loss of over \$100 million (Bangsund and Leistritz 1991). Losses are due to reduced carrying capacity, reduced land value, and cost of control. There are several long-term management alternatives for leafy spurge control with herbicides. Picloram (4-amino-3,5,6trichloro-2-pyridinecarboxylic acid) at $2.2 \mathrm{~kg}$ ae/ha will provide greater than $90 \%$ leafy spurge control for at least 2 growing seasons, but is cost prohibitive except as a spot-treatment (Lym and Messersmith 1985, Bangsund et al. 1996). The most common herbicide treatment for leafy spurge control on large infestations is picloram plus 2,4-D [2,4-dichlorophenoxy)acetic acid] at 0.3 plus $1.1 \mathrm{~kg}$ ae/ha applied during the true-flower growth stage. This treatment controls leafy spurge top-growth in 3 to 5 years (Lym and Messersmith 1990). However, picloram cannot be applied in environmentally sensitive areas such as those with high water tables or those prone to flooding.

Manuscript accepted 28 Mar. 1999
Resumen

En 3 localidades de North Dakota se evaluó el control de "Leafy spurge" con glifosato [(N-(fosfonometil)glicine] mas 2,4D [(2,4-diclorofenoxi) ácido acético], aplicado anualmente durante tres años solo o rotado con herbicidas a base de auxina. Después de 3 meses de la aplicación, la mezcla de glifosato con 2,4-D controló el $67 \%$ del " Leafy spurge", y el control fue 10 veces mayor que el obtenido con el glifosato solo. El glifosato mas 2,4-D aplicado anualmente por 3 años o rotado con dicamba (3,6-dicloro-2 ácido metooxibenzoico) o picloram (4-amino-3,5,6tricloro-2acido piridinecarboxilico) mas 2,4-D controlaron del 80 al $90 \%$ del "Leafy spurge", que fue similar al control obtenido con el tratamiento estándar de aplicaciones anuales de picloram mas 2,4-D, pero con una reducción de costos entre 30 al $65 \%$. La producción de forraje fue similar independientemente del tratamiento. La absorción y translocación del ${ }^{14} \mathrm{C}-2,4-\mathrm{D}$ se incrementó de 2 a 3 veces cuando se aplicó con glifosato en comparación con la aplicación sola de ${ }^{14} \mathrm{C}-2,4-\mathrm{D}$. Sin embargo, la absorción y translocación de $1^{14} \mathrm{C}$-glifosato fue severamente reducida cuando se aplicó con 2,4-D comparado con el 14C-glifosato aplicado solo. El aumento en el control de "Leafy spurge" cuando se aplicó glifosato con $2,4-\mathrm{D}$ puede deberse a que concentraciones subletales de glifosato rompen la dormancia de la yemas del "Leafy spurge", por lo tanto, se incrementa la cantidad de 2,4-D en las raíces. Glifosato mas $2,4-D$ proveen un buen control de "Leafy spurge" a menor costo que los tratamientos actuales y debe proveer una nueva herramienta para el manejo de "Leafy spurge"

Glyphosate [ $N$-(phosphonomethyl)glycine] at $0.8 \mathrm{~kg}$ ae/ha fallapplied will provide 80 to $90 \%$ leafy spurge control 12 MAFT (months after the first treatment) (Lym and Messersmith 1985), but glyphosate is nonselective and its use is limited to shelterbelts and as a spot treatment in rangeland. Glyphosate is often applied with 2,4-D for broad spectrum weed control in cropland. The combination of glyphosate plus 2,4-D has resulted in reduced grass control compared to glyphosate applied alone (O'Sullivan and O'Donovan 1980, Flint and Barrett 1989), but can be synergistic for broadleaf weed control. The addition of 2,4-DB [4-(2,4dichlorophenoxy)butanoic acid] to glyphosate was either additive or synergistic for control of various morningglory (Convolvulus) species (Wehtje and Walker 1997), and 2,4-D did not antagonize glyphosate control for purple netsedge (Cyperus rotundus L.) Suwunnamer and Parker 1975).

In North Dakota, glyphosate applied with $2,4-\mathrm{D}$ at 0.45 plus 0.7 $\mathrm{kg} / \mathrm{ha}$ in the fall provided greater than $85 \%$ leafy spurge control but caused 30 to $90 \%$ grass injury depending on location and 
associated grass species (Lym and Messersmith 1994). To avoid severe grass injury, especially to native cool-season species such as western wheatgrass (Agropyron smithii Rydb.) and Canada wildrye (Elymus canadensis L.) glyphosate plus 2,4-D was annually rotated with picloram plus $2,4-\mathrm{D}$ at 0.6 plus 1 $\mathrm{kg} / \mathrm{ha}$ or dicamba $(3,6$-dichloro-2methoxybenzoic acid) at $2.2 \mathrm{~kg}$ ae/ha. This rotation resulted in $90 \%$ or greater leafy spurge control and only minor to moderate grass injury, but the practice increased the cost of the control program (Lym and Kirby 1991).

Glyphosate plus 2,4-D at 0.45 plus 0.7 $\mathrm{kg} / \mathrm{ha}$ costs approximately $35 \%$ less than the standard spring-applied rate of picloram plus 2,4-D. Adding a glyphosate plus $2,4-\mathrm{D}$ treatment to a leafy spurge management program could annually save thousands of dollars in herbicide costs. These savings would make some herbage reduction by glyphosate plus 2,4-D acceptable if the resulting control were similar to or better than presently used herbicide treatments. The purpose of this research was to evaluate leafy spurge control with spring applications of glyphosate plus 2,4-D applied annually or applied in a rotation with other herbicides. The effect of glyphosate applied with 2,4-D on the absorption and translocation of each herbicide in leafy spurge was also evaluated.

\section{Materials and Methods}

Leafy spurge control. A field study to evaluate differences in leafy spurge control with glyphosate used alone and the combination of glyphosate plus 2,4-D was conducted on ungrazed dense stands of leafy spurge $\left(>100 \mathrm{stems} / \mathrm{m}^{2}\right)$ at 3 locations, Fort Ransom, Jamestown, and Walcott, N.D. Smooth brome (Bromus inermis Leyss.) and western wheatgrass [Pascopyrum smithii (Rydb.) Love] were the predominate grass species at the Fort Ransom and Walcott locations and Kentucky bluegrass (Poa pratensis L.) was the predominate grass at Jamestown. The experimental locations had at least $80 \%$ ground cover of leafy spurge with limited amounts of other perennial plants such as western snowberry (Symphoricarpos occidentalis Hook.), prairie wild rose (Rosa arkansana Porter), and Canada thistle (Cirsium arvense L.).

Soils at Fort Ransom were a FormanAastad loam (fine-loamy, mixed Udic Argiborolls; fine-loamy; fine loamy, mixed Pachic Udic Haploborolls; 7\%) organic matter and $6.8 \mathrm{pH}$, at Jamestown were a Fordville loamy sand (fine-loamy over sandy or sandy skeletal, mixed Pachic Udic Haploborolls; 6.8\% organic matter and $\mathrm{pH}$ 6.8), and at Walcott were a Tiffany fine sandy loam (coarse-loamy, mixed, Typic Endoaquolls; $2.9 \%$ organic matter and $6.8 \mathrm{pH}$ ).

Glyphosate alone at $0.45 \mathrm{~kg} / \mathrm{ha}$ or glyphosate plus $2,4-\mathrm{D}^{1}$ at 0.45 plus 0.7 $\mathrm{kg} / \mathrm{ha}$ were applied annually for 3 years to the same plots or were alternated with auxin herbicides. The auxin herbicide treatments were selected based on cost and efficacy of leafy spurge control as determined from previous research (Lym and Messersmith 1985, Lym and Messersmith 1990 ), included picloram plus 2,4-D at 0.28 plus $1.1 \mathrm{~kg} / \mathrm{ha}$ and dicamba at 2.2 $\mathrm{kg} / \mathrm{ha}$.

Herbicides were applied using a tractormounted $\mathrm{CO}_{2}$-pressurized sprayer equipped with flat fan 8001 nozzles $^{2}$, delivering 80 liter/ha. The initial treatments were applied at the optimum leafy spurge growth stage for control for the respective herbicides, i.e. picloram plus 2,4-D and dicamba were applied in midJune 1995 during the leafy spurge trueflower growth stage, while glyphosate alone and alyphosate plus 2,4-D were applied in late June during seed-set. Retreatments were applied in early to midJuly 1996 and 1997 when leafy spurge was in the vegetative to flowering growth stage. Leafy spurge maturity following the initial treatments were delayed due to herbicide effects the previous season.

Experimental units were 2.4 by $9.1 \mathrm{~m}$ with a 1-m border between each plot and were replicated 4 times at all locations. Leafy spurge stand reduction and grass injury were evaluated each June and September beginning 3 months after the first treatment. Evaluations of both leafy spurge stand reduction (control) and grass injury were appraised on a scale of 0 to 100 , with 0 equal to no stand reduction or grass injury and 100 equal to complete absence of aboveground leafy spurge plants or no perennial grass as compared to plants in the border and the untreated control. In the final year of evaluation (1998), leafy spurge control was determined by counting the number of stems in four, $0.25-\mathrm{m}^{2}$ quadrats per plot and data were used to calculate percent control based on stem reduction. Also, two, 0.25$\mathrm{m}^{2}$ quadrats per treatment were clipped and separated into leafy spurge and

\footnotetext{
${ }^{1}$ Commercial formulation, Campaign by Monssanto Company, St. Louis, Mo. 63167.

${ }^{2}$ Teejet flat fan spray tips, Spraying Systems Co., Box 7900, Wheaton, Ill. 60189.
}

herbage components. The samples were oven dried at $60^{\circ} \mathrm{C}$ for 72 hours.

Economic comparisons were based on the total herbicide cost for the 3 annual treatments. Application costs were not included as they vary by method of application and terrain and would be the same for each treatment. The average herbicide costs used for economic analysis were 2,4$\mathrm{D}$ amine at $\$ 6.50 / \mathrm{kg}$, dicamba at $\$ 44 / \mathrm{kg}$, glyphosate at $\$ 37 / \mathrm{kg}$, glyphosate plus 2,4 $\mathrm{D}^{1}$ at $\$ 19 / \mathrm{kg}$ (144 g glyphosate isopropylamine plus $227 \mathrm{~g} 2,4-\mathrm{D}$ isopropylamine/liter), and picloram at $\$ 88 / \mathrm{kg}$.

Absorption and translocation. The absorption and translocation of glyphosate and 2,4-D in vegetative and flowering leafy spurge plants were evaluated in laboratory studies. Leafy spurge plants were propagated from 1 accession and grown as previously described (Lym 1992). Approximately 6 weeks after planting, the topgrowth was removed at the soil surface, and 1 stem per pot was allowed to regrow for 60 or 90 days to provide plants in the vegetative and flowering growth stages, respectively.

Mixtures of ${ }^{14} \mathrm{C}$-glyphosate isopropylamine and ${ }^{14} \mathrm{C}-2,4-\mathrm{D}$ technical acid were prepared by mixing with excess isopropylamine and allowing the excess isopropylamine to evaporate. Approximately $5 \mu \mathrm{l}$ of $0.15 \%(\mathrm{v} / \mathrm{v})$ surfactant MON $-0818^{3}$ in $\mathrm{H}_{2} 0$ was applied to $1 \mathrm{~cm}^{2}$ each on 2 fully expanded leaves midway on the stem; the surfactant solution also included unlabeled glyphosate or 2,4-D to achieve an application rate equivalent to the broadcast field rate. Immediately thereafter $1700 \mathrm{~Bq} / \mathrm{leaf}$ of uniformly ring labeled ${ }^{14} \mathrm{C}$-glyphosate (specific activity $2.0 \mathrm{GBq} / \mathrm{mmole}$ ) isopropylamine in $5 \mu \mathrm{H}_{2} 0$ or $1700 \mathrm{~Bq} / \mathrm{leaf}$ of phenyl ring-labeled ${ }^{14} \mathrm{C}-2,4-\mathrm{D}$ (specific activity $1.0 \mathrm{GBq} / \mathrm{mmole}$ ) isopropylamine in $5 \mu \mathrm{l}$ of $50 \%$ ethanol: $\mathrm{H}_{2} \mathrm{O}(\mathrm{v} / \mathrm{v})$ was added to the treated area. The treatments consisted of a) ${ }^{14} \mathrm{C}$-glyphosate, b) ${ }^{14} \mathrm{C}$ glyphosate plus $2,4-\mathrm{D}, \mathrm{c}){ }^{14} \mathrm{C}-2,4-\mathrm{D}$, and d) ${ }^{14} \mathrm{C}-2,4-\mathrm{D}$ plus glyphosate.

Plants were harvested 72 hours after application and divided into treated leaves, shoot above treated leaves, shoot below treated leaves, and roots 0 to $6 \mathrm{~cm}$ below the soil surface. The treated leaf was hand swirled in $1 \mathrm{ml}$ of $\mathrm{H}_{2} \mathrm{O}$ for 10 seconds to remove unabsorbed water-soluble ${ }^{14} \mathrm{C}$. Then $15 \mathrm{ml}$ of liquid scintillation cocktail' A' \{toluene:ethanol, 1:1 v/v, with 5 g/liter PPO (2,5-diphenyloxazole) and 0.5 g/liter dimethyl-POPOP [1,4-bis-2-(4methyl-5-phenyloxazolyl) benzene]\} was

\footnotetext{
${ }^{3}$ Monsanto, St. Louis, Mo. 63167.
} 
added and the treated leaf was dipped 10 times to remove the remaining unabsorbed ${ }^{14} \mathrm{C}$. The ${ }^{14} \mathrm{C}$ was quantified using liquid scintillation spectrometry ${ }^{4}$, and absorption was determined by subtracting ${ }^{14} \mathrm{C}$ in the leaf wash from the total ${ }^{14} \mathrm{C}$ applied.

The plant sections were first frozen for 24 hours at $-18^{\circ} \mathrm{C}$, then dried for 48 hours at $60^{\circ} \mathrm{C}$, and weighed. The plant material was combusted, using a biological materials ozidizer ${ }^{5}$. The ${ }^{14} \mathrm{CO}_{2}$ was collected in $15 \mathrm{ml}$ of liquid scintillation cocktail ' $\mathrm{B}$ ' (toluene:2-methoxyethanol:ethanolamine, 10:7:3 v/v/v, with $5 \mathrm{~g} /$ liter PPO and 0.5 g/liter dimethyl-POPOP) and was quantified using liquid scintillation spectrometry.

Statistical analysis. Field experiments were arranged as a randomized complete block design with 4 replications and were analyzed using the general linear models procedure with the Fisher's protected LSD mean separation technique (SAS 1990). Experimental errors were tested for homogeneity of variance using Bartlett's Chi Square test. All experimental errors were homogeneous: thus, combined analysis of variance across locations are shown. The absorption and translocation experiment was in a randomized complete block design with 4 replicates and was duplicated. Treatment means were separated using a Fisher's-protected LSD at the 95\% probability level. The data for each ${ }^{14} \mathrm{C}$ experimental had similar variance when repeated therefore data were combined.

\section{Results and Discussion}

Leafy spurge control. Three months after the first treatment, glyphosate applied with $2,4-\mathrm{D}$ provided a 10 -fold increase in leafy spurge control compared to glyphosate alone and was greater than the standard treatment of picloram plus 2,4-D (Table 1). The 3 first year treatments that started with glyphosate plus $2,4-\mathrm{D}$ at 0.45 plus $0.7 \mathrm{~kg} / \mathrm{ha}$ averaged $67 \%$ leafy spurge control 3 months after the first treatment compared to only $7 \%$ control with the 2 treatments starting with glyphosate at $0.45 \mathrm{~kg} / \mathrm{ha}$ applied alone. Leafy spurge control was similar when the glyphosate plus 2,4-D rate was reduced by $25 \%$ to 0.33 plus $0.53 \mathrm{~kg} / \mathrm{ha}$, but control declined when the application rate was reduced by $50 \%$.

Leafy spurge control with glyphosate plus 2,4-D at 0.45 plus $0.7 \mathrm{~kg} / \mathrm{ha}$ and 0.33

\footnotetext{
${ }^{4}$ Beckman LS 6800 liquid scintillation spectrometer. Beckman Instruments, Irvine, Calif. 92713.

${ }^{5}$ Harvey Model OX-400 biological materials oxidizer. R.J. Harvey Instrument Corporation, Hillsdale, N.J. 07642
}

Table 1. Leafy spurge control with glyphosate plus 2,4-D applied annually for 3 years or rotated with auxin herbicides averaged over 3 locations in North Dakota.

\begin{tabular}{|c|c|c|c|c|c|c|c|c|}
\hline \multirow{2}{*}{\multicolumn{2}{|c|}{1995 and 1997}} & \multirow{2}{*}{\multicolumn{2}{|c|}{1996}} & \multicolumn{5}{|c|}{$\overline{\text { Treatment year/MAFT }}^{1}$} \\
\hline & & & & \multicolumn{2}{|c|}{1995} & \multirow{2}{*}{$\frac{95 \& 96}{24}$} & \multirow{2}{*}{$\frac{95-97}{36}$} & \multirow{2}{*}{$\begin{array}{r}\text { Total } \\
\text { cost }\end{array}$} \\
\hline Treatment & Rate & Treatment & Rate & 3 & 12 & & & \\
\hline & $(\mathrm{kg} / \mathrm{ha})$ & & $(\mathrm{kg} / \mathrm{ha})$ & --( & con & rol) - - & & (\$/ha) \\
\hline Glyphosate $+2,4-\mathrm{D}^{2}$ & $0.45+0.7$ & Glyphosate $+2,4-\mathrm{D}^{2}$ & $0.45+0.7$ & 65 & 61 & 65 & 85 & 66 \\
\hline Glyphosate + 2,4-D ${ }^{2}$ & $0.45+0.7$ & Picloram + 2,4-D & $0.28+1.1$ & 67 & 72 & 76 & 91 & 77 \\
\hline Glyphosate $+2,4-\mathrm{D}^{2}$ & $0.45+0.7$ & Dicamba & 2.2 & 68 & 64 & 60 & 79 & 146 \\
\hline Picloram + 2,4-D & $0.28+1.1$ & Picloram + 2,4-D & $0.28+1.1$ & 50 & 36 & 80 & 90 & 96 \\
\hline Dicamba $+2,4-D$ & 2.2 & Dicamba & 2.2 & 52 & 37 & 68 & 69 & 290 \\
\hline Glyphosate & 0.45 & Picloram + 2,4-D & $0.28+1.1$ & 7 & 44 & 74 & 73 & 64 \\
\hline Glyphosate & 0.45 & Dicamba & 2.2 & 6 & 43 & 49 & 83 & 131 \\
\hline Glyphosate $+2,4-D^{2}$ & $0.22+0.35$ & Glyphosate $+2,4-D^{2}$ & $0.22+0.35$ & 51 & 39 & 51 & 82 & 33 \\
\hline Glyphosate $+2,4-\mathrm{D}^{2}$ & $0.33+0.53$ & Glyphosate $+2,4-\mathrm{D}^{2}$ & $0.33+0.53$ & 62 & 63 & 54 & 81 & 49 \\
\hline $\operatorname{LSD}(0.05)$ & & & & 13 & 16 & 17 & 9 & \\
\hline
\end{tabular}

${ }^{\mathrm{T}}$ Months after first treatment in 1995.

${ }^{2}$ Commercial formulation-Campaign by Monsanto Company, St. Louis, Mo. 63167.

plus $0.53 \mathrm{~kg} / \mathrm{ha}$ remained consistent between the 3 and 12 months after the first treatment evaluations and averaged $65 \%$ 12 months after the first treatment (Table 1). In contrast leafy spurge control with the standard treatment of picloram plus 2,4-D declined from $50 \% 3$ months after the first treatment to $36 \% 12$ months after the first treatment. Control with glyphosate alone increased to $44 \%$ between evaluation dates. The plants treated with glyphosate alone were much shorter than untreated plants throughout the summer and exhibited multiple branching from the root crown.

Treatments that included picloram plus 2,4-D in the second year of the rotation (1996) tended to provide the best leafy spurge control 24 months after the treatment (Table 1). Leafy spurge control averaged $77 \%$ when picloram plus $2,4-\mathrm{D}$ was applied 2 consecutive years or when preceded by glyphosate or glyphosate plus 2,4-D. Glyphosate plus 2,4-D applied at 0.45 plus $0.7 \mathrm{~kg} / \mathrm{ha}$ for 2 consecutive years averaged $65 \%$ leafy spurge control, and control still averaged over $50 \%$ when the application rate was reduced by 25 or $50 \%$.

Glyphosate plus 2,4-D applied annually for 3 years or rotated with auxin herbicides provided similar control as the standard picloram plus 2,4-D treatment but at 30 to $65 \%$ less cost (Table 1). Glyphosate plus $2,4-\mathrm{D}$ at rates from 0.22 plus 0.35 to 0.45 plus $0.7 \mathrm{~kg} / \mathrm{ha}$ averaged $83 \%$ leafy spurge control 1 year after the last application (36 months after the first treatment) compared to $90 \%$ for the standard picloram plus 2,4-D treatment. When the glyphosate plus 2,4-D treatment was rotated with picloram plus 2,4-D control averaged $91 \%$ but the total cost of the 3 years treatment program increased by $\$ 11 /$ ha compared to an annual application of glyphosate plus $2,4-\mathrm{D}$ at 0.45 plus 0.7 $\mathrm{kg} / \mathrm{ha}$. Likewise, annual treatments with either glyphosate plus $2,4-\mathrm{D}$ at 0.45 plus $0.7 \mathrm{~kg} / \mathrm{ha}$ or picloram plus $2,4-\mathrm{D}$ provided similar leafy spurge control but glyphosate plus 2,4-D was $\$ 30 /$ ha less expensive. Dicamba at $2.2 \mathrm{~kg} / \mathrm{ha}$ had the highest cost of $\$ 290 /$ ha for 3 annual treatments, but provided only an average of $69 \%$ leafy spurge control. Rotation of glyphosate plus 2,4-D with dicamba provided less leafy spurge control than glyphosate plus 2,4-D either applied alone for 3 consecutive years or rotated with picloram plus 2,4-D.

Despite good leafy spurge control at lower costs, land managers are concerned that glyphosate plus 2,4-D applied in pasture and rangeland will injure or kill desirable grass species since glyphosate is nonselective. However, glyphosate plus 2,4-D annually applied for 3 years averaged $15 \%$ or less grass injury 36 months after the first treatment (12 months after the final treatment) (Table 2). Initial grass injury averaged approximately $30 \% 3$ months after the first treatment following the third consecutive application. As the glyphosate plus 2,4-D rate was reduced by 25 or $50 \%$, grass injury was minimal to not visible 36 months after the first treatment.

Yield data confirmed that glyphosate plus 2,4-D controlled leafy spurge similar to the standard treatment of picloram plus 2,4-D and did not reduce herbage production (Table 3). Glyphosate plus 2,4-D at 0.45 plus $0.7 \mathrm{~kg} / \mathrm{ha}$ annually applied for 3 years reduced leafy spurge production nearly $90 \% 1$ year after the last application compared to $2,205 \mathrm{~kg} / \mathrm{ha}$ in the untreated control. Herbage production was similar regardless of herbicide treatment and is often slow to recover when leafy spurge is controlled by herbicides (Lym and Messersmith 1990). The slow recovery in 
Table 2. Grass injury with glyphosate plus 2,4-D applied annually for 3 years or rotated with auxin herbicides averaged over 3 locations in North Dakota.

\begin{tabular}{|c|c|c|c|c|c|c|c|c|c|}
\hline & & & & \multicolumn{6}{|c|}{$\overline{\text { Treatment year/MAFT }}^{1}$} \\
\hline \multicolumn{2}{|c|}{1995 and 1997} & \multicolumn{2}{|c|}{1996} & \multicolumn{2}{|c|}{1995} & \multicolumn{2}{|c|}{$95 \& 96$} & \multicolumn{2}{|c|}{$95-97$} \\
\hline Treatment & Rate & Treatment & Rate & 3 & 12 & 15 & 24 & 27 & 36 \\
\hline & $(\mathrm{kg} / \mathrm{ha})$ & & (kg/ha) & $-\cdots$ & $-\ldots$ & 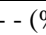 & y) & -- & -- \\
\hline Glyphosate $+2,4-\mathrm{D}^{2}$ & $0.45+0.7$ & Picloram + 2,4-D & $0.28+1.1$ & 26 & 0 & 6 & 0 & 21 & 1 \\
\hline Glyphosate $+2,4-D^{2}$ & $0.45+0.7$ & Dicamba & 2.2 & 31 & 0 & 0 & 0 & 25 & 5 \\
\hline Picloram + 2,4-D & $0.28+1.1$ & Picloram + 2,4-D & $0.28+1.1$ & 0 & 0 & 3 & 0 & 4 & 0 \\
\hline Glyphosate & 0.45 & Dicamba & $0.22+0.35$ & 10 & 0 & 4 & 0 & 6 & 4 \\
\hline Glyphosate $+2,4-\mathrm{D}^{2}$ & $0.22+0.35$ & Glyphosate $+2,4-\mathrm{D}^{2}$ & $0.33+0.53$ & 19 & 0 & 5 & 0 & 8 & 4 \\
\hline Glyphosate $+2,4-\mathrm{D}^{2}$ & $0.33+0.53$ & Glyphosate $+2,4-\mathrm{D}^{2}$ & $0.33+0.53$ & 19 & 0 & 2 & 0 & 17 & 0 \\
\hline $\operatorname{LSD}(0.05)$ & & & & 12 & NS & 9 & NS & 7 & 4 \\
\hline
\end{tabular}

Months after first treatment in 1995.

${ }^{2}$ Commercial formulation-Campaign by Monsanto Company, St. Louis, Mo. 63167.

production may be due to the deep leafy spurge root system that is still competing for moisture and nutrients even though there may be very little visible topgrowth.

The addition of 2,4-D to glyphosate appears to reduce the efficacy of glyphosate on grasses. Glyphosate plus 2,4-D has reduced control of several grass species including wild oat (Avena fatua L.) (O’Sullivan and O’Donovan 1980), Johnsongrass (Sorghum halepense L.) (Flint and Barrett 1989), and wheat (Triticum aestivum L.) (Nalewaja and Matysiak 1992) compared to glyphosate alone. The reason for reduced control has been attributed to reduced glyphosate uptake and translocation (Flint and Barrett 1989) caused by formation of various glyphosate salts with either the 2,4-D molecule or associated compounds within the formulation (Thelen et al. 1995). Thelen et al. (1995) also reported a change in the molecular orientation of the glyphosate molecule caused by $2,4-\mathrm{D}$, which probably accounts for the reduced absorption of glyphosate in the presence of 2,4-D.

Table 3. Herbage and leafy spurge yield the season following 3 annual applications of glyphosate plus 2,4-D applied alone or rotated with auxin herbicides averaged over 3 locations in North Dakota.

\begin{tabular}{|c|c|c|c|c|c|}
\hline \multicolumn{2}{|c|}{1995 and 1997} & \multicolumn{2}{|l|}{1996} & \multicolumn{2}{|c|}{1998 yield } \\
\hline Treatment & Rate & Treatment & Rate & $\begin{array}{l}\text { Leafy } \\
\text { Spurge }\end{array}$ & Herbage \\
\hline & $(\mathrm{kg} / \mathrm{ha})$ & & $(\mathrm{kg} / \mathrm{ha})$ & \multicolumn{2}{|c|}{----(kg/ha)---- } \\
\hline Glyphosate $+2,4-\mathrm{D}^{2}$ & $0.45+0.7$ & Glyphosate $+2,4-\mathrm{D}^{1}$ & $0.45+0.7$ & 230 & 2695 \\
\hline Glyphosate $+2,4-\mathrm{D}^{2}$ & $0.45+0.7$ & Picloram + 2,4-D & $0.28+1.1$ & 190 & 3270 \\
\hline Glyphosate $+2,4-D^{2}$ & $0.45+0.7$ & Dicamba & 2.2 & 245 & 2660 \\
\hline Picloram + 2,4-D & $0.28+1.1$ & Picloram + 2,4-D & $0.28+1.1$ & 140 & 3030 \\
\hline Dicamba + 2,4-D & 2.2 & Dicamba & 2.2 & 205 & 2625 \\
\hline Glyphosate & 0.45 & Picloram+2,4-D & $0.28+1.1$ & 340 & 2600 \\
\hline Glyphosate & 0.45 & Dicamba & 2.2 & 375 & 2570 \\
\hline Glyphosate $+2,4-\mathrm{D}^{2}$ & $0.22+0.35$ & Glyphosate $+2,4-\mathrm{D}^{1}$ & $0.22+0.35$ & 320 & 3120 \\
\hline Glyphosate $+2,4-D^{2}$ & $0.33+0.53$ & Glyphosate $+2,4-\mathrm{D}^{1}$ & $0.33+0.53$ & 300 & 2530 \\
\hline Control & & Control & & 2205 & 2030 \\
\hline $\operatorname{LSD}(0.05)$ & & & & 360 & 755 \\
\hline
\end{tabular}

${ }^{\mathrm{C}}$ Commercial formulation-Campaign by Monsanto Company, St. Louis, Mo. 63167.
Glyphosate plus 2,4-D annually applied can result in moderate to severe grass injury, especially in dry seasons and/or on certain grass species such as western wheatgrass (Lym and Kirby 1991). To avoid grass injury, a land manager could rotate glyphosate plus 2,4-D with picloram plus 2,4-D in alternate years. The increase in treatment costs of approximately $15 \%$ per acre would need to be considered versus the potential for grass injury and loss of herbage production.

The dramatic increase in leafy spurge control when glyphosate was applied with 2,4-D compared to glyphosate alone was surprising. Glyphosate alone applied in spring generally provides poor leafy spurge control especially when applied prior to seed-set (Lym and Messersmith 1985). The application of 2,4-D annually or even biannually provides only short term control of leafy spurge topgrowth. The leafy spurge root system is not killed by 2,4-D because, even though foliar absorption is relatively high $(>25 \%$ of applied), translocation to the root is low

. The increase in weed control when 2
herbicides are applied together, compared to either alone is generally from an increase in either absorption and/or translocation of one of the components or a change in the metabolism of the herbicide(s) within the plant (Hatzios and Penner 1985). But neither explanation seems likely to adequately explain the increased control of leafy spurge when treated with glyphosate plus 2,4-D. Since both absorption and translocation of glyphosate were severely reduced, the increase in control seems likely due to the 2,4-D component. However, 2,4-D typi- 
Table 4. Glyphosate and 2,4-D absorption and translocation in leafy spurge at 2 growth stages.

\begin{tabular}{|c|c|c|c|c|c|}
\hline \multirow[b]{2}{*}{ Treatment } & \multirow[b]{2}{*}{$\begin{array}{l}\text { Growth } \\
\text { stage }^{1}\end{array}$} & \multirow[b]{2}{*}{ Absorbed } & \multicolumn{3}{|c|}{ Plant section $^{2}$} \\
\hline & & & ATL & BTL & Root \\
\hline & & \multicolumn{4}{|c|}{$\ldots \ldots \ldots$ - $(\%$ of applied $) \ldots \ldots$} \\
\hline $\mathrm{C}^{14}$ Glyphosate & Veg-flwr & 38 & 2.8 & 8.2 & 13.1 \\
\hline $\mathrm{C}^{14} 2,4-\mathrm{D}$ & Veg-flwr & 23 & 0.7 & 3.0 & 1.2 \\
\hline $\mathrm{C}^{14}$ Glyphosate + 2,4-D & Veg-flwr & 20 & 0.4 & 1.4 & 5.3 \\
\hline $\mathrm{C}^{14} 2,4-\mathrm{D}+$ glyphosate & Veg-flwr & 76 & 2.8 & 5.0 & 3.4 \\
\hline $\mathrm{C}^{14}$ Glyphosate & Seed-set & 55 & 4.5 & 11.1 & 21.4 \\
\hline $\mathrm{C}^{14} 2,4-\mathrm{D}$ & Seed-set & 18 & 1.2 & 2.8 & 0.6 \\
\hline $\mathrm{C}^{14}$ Glyphosate + 2,4-D & Seed-set & 26 & 1.5 & 2.8 & 7.2 \\
\hline $\mathrm{C}^{14} 2,4-\mathrm{D}+$ glyphosate & Seed-set & 55 & 2.9 & 8.5 & 1.3 \\
\hline LSD (0.05) & & 8 & 2 & 4.5 & 3.8 \\
\hline
\end{tabular}

${ }^{1}$ Veg-flwr = vegetative to flowering

${ }^{2} \mathrm{ATL}=$ stem and leaves above the treated leaf; $\mathrm{BTL}=$ stem and leaves below the treated leaf.

cally provides only short-term leafy spurge control of 4 to 6 weeks (Lym and Messersmith 1985).

Labeled 2,4-D generally remains as the parent acid in leafy spurge when applied alone or with picloram (Lym and Moxness 1989). Since 2,4-D generally remains unmetabolized in leafy spurge, a reduction in 2,4-D metabolism by the presence of glyphosate does not seem a like cause of the increased control. The increase in control when picloram was applied with 2,4-D compared to either alone was due to an increase in unmetabolized picloram translocated to the roots (Lym and Moxness 1989). Perhaps 2,4-D is decreasing glyphosate metabolism in leafy spurge, but a change in metabolism seemingly would not compensate for the large reduction in glyphosate absorption and translocation.

The increase in control when glyphosate is applied with 2,4-D may be because glyphosate at sublethal concentrations alters the bud dormancy regulation system in leafy spurge resulting in a proliferation of new shoots arising from the roots (Maxwell et al. 1987), commonly termed "witches brooming". Glyphosate apparently interfered with correlative inhibition which facilitated prolific shoot bud growth from previously inhibited buds on the leafy spurge root. The release of root bud dormancy could cause an increase in basipetal translocation of 2,4-D to the roots (as observed in this study) because the proliferation in growth would create a metabolic sink. Witches brooming was observed following application of both glyphosate alone and glyphosate plus 2,4$\mathrm{D}$ in the field portion of theses studies.

Hunter and McIntyre (1974) reported that decapitation of leafy spurge stems released apical dominance in leafy spurge root buds and increased the amount of ${ }^{14} \mathrm{C}$ 2-D translocated throughout the plant, including a 5-fold increase to the root

\section{Literature Cited}

Bangsund, D.A. and F.L. Leistritz. 1991. Economic impact of leafy spurge in Montana, South Dakota, and Wyoming. Agr. Econ. Rep. 275. North Dakota State Univ., Fargo, N.D. 58105.

Bangsund, D.A., J.A. Leitch, and F.L. Leistritz. 1996. Economics of herbicide control of leafy spurge (Euphorbia esula. L.). J. Agr. Resource Econ. 21:381-395.

Flint, J.L. and M.Barrett. 1989. Antagonism of glyphosate toxicity to johnsongrass by 2,4-D and dicamba. Weed Sci. 37:700-705.

Hatzios, K.K. and D. Penner. 1985. Interactions of herbicides with other agrochemicals in higher plants. Rev. Weed Sci. 1:1-63.

Hunter, J.H. and G.I. McIntyre. 1974. Factors affecting translocation of 2,4-D in leafy spurge. Weed Sci. 22:167-171.

Lym, R.G. 1992. Propagation of Euphorbia esula for leafy spurge biocontrol agents. Weed Sci. 40:326-332.

Lym, R.G. and D.R. Kirby. 1991. Effect of glyphosate on introduced and native grasses. Weed Technol. 5:421-425.

Lym, R.G. and C.G. Messersmith. 1985. Leafy spurge control with herbicides in North Dakota:20-yr summary. J. Range Manage. 38:149-154.

Lym, R.G. and C.G. Messersmith. 1990. Cost-effective long-term leafy spurge control with herbicides. Weed Technol. 4:635-641.

Lym, R.G. and C.G. Messersmith. 1994. Leafy spurge (Euphorbia esula) control forage production, and economic return with fall-applied herbicides. Weed Technol. 8:824-829.

\section{Conclusions}

The herbicide combination glyphosate plus 2,4-D should become part of a land managers long-term leafy spurge control program. The combination treatment provided similar control to the standard picloram plus 2,4-D treatment in this 4 year study at 30 to $65 \%$ less cost. Herbage reduction was short-term even when glyphosate plus 2,4-D was applied annually for 3 years. Although glyphosate uptake and translocation is antagonized by $2,4-\mathrm{D}$, grass injury may remain a concern for some land managers. Then the glyphosate plus 2,4-D treatment cold be rotated with picloram plus 2,4-D, because this treatment program provided greater than $90 \%$ control in 3 years and at least a $2^{\circ} \%$ cost savings compared to an annual application of picloram plus 2,4-D.

Lym, R.G. and K.D. Moxness. 1989. Absorption, translocation, and metabolism of picloram and 2,4-D in leafy spurge (Euphorbia esula). Weed Sci. 37:498-502.

Maxwell, B.D., M.E. Foley, and P.K. Fay. 1987. The influence of glyphosate on bud dormancy in leafy spurge (Euphorbia esula). Weed Sci. 35:6-10.

Nalewaja, J.D. and R. Matysiak. 1992. 2,4-D and salt combinations affect glyphosate phytotoxicity. Weed Technol. 6:322-327.

O'Sullivan, P.A. and J.T. O'Donovan. 1980. Interaction between glyphosate and various herbicides for broadleaf weed control. Weed Res. 20:225-260.

Statistical Analysis System Institute. 1990. SAS/STAT User's Guide: Statistics, Cary, N.C.

Suwunnamer, V. and C. Parker. 1975. Control of Cyperus rotundus with glyphosate: the influence of ammonium sulfate and other additives. Weed Res. 16:13-19.

Thelen, K.D., E.P. Jackson, and D. Penner. 1995. 2,4-D interactions with glyphosate and sodium bicarbonate. Weed Technol. 9:301-305.

Wehtje, G. and R.H. Walekr 1997. Interaction of glyphosate and 2,4-DB for the control of selected morningglory (Ipomoea spp.) species. Weed Technol. 11:152-156. 